\title{
Investigating the Gap between Simultaneous Interpreter Training and Iraqi Market Needs
}

\author{
Assist. Prof. Jasim Al-Maryani \\ Dept. of Translation \\ College of Arts University of Basrah
}

Abstract

After the war in 2003, interpreting became one of the most prominent professions in Iraq. Huge numbers of interpreters were recruited to facilitate communication between military troops and reconstruction international corporations on the one hand and the Iraqi public on the other. Moreover, there was a gradual high demand for interpreters in the market to cater for the needs of the rapidly increasing foreign direct investment in many fields such as the oil industry. However, interpreter training programmes offered by Iraqi universities and several independent institutions remain as poorly designed as they have always been: they fail to meet the requirements of such social and global changes. The present study evaluates simultaneous interpreting training in Iraq. It calls for the revision, renewal, and continuous update of curricula and teaching methodology to suit the critical challenges posed by the digital modern market. It also suggests a number of possible workable solutions to improve interpreter training such as devoting well-trained teaching staff, offering specialized training programmes for the would-be interpreters, raise programme standards and the integration of technology into teaching.

Keywords, Interpreter training, curricula, social and global market

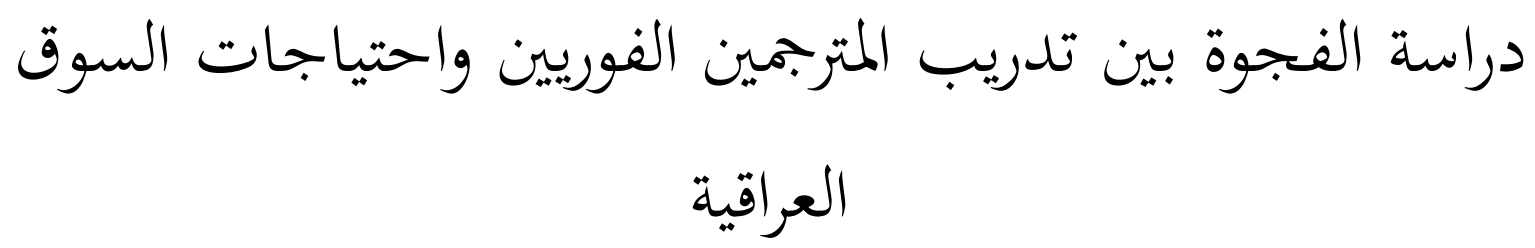

$$
\text { ا.مسم الترجمة/كلية الآداب/ جاسم خليفة سلطان المرياني }
$$

بعد الحرب في عام 2003 ، أصبحت التزبمة الفورية احدى اهم المهن في العراق. حيث تم توظيف أعداد كبيرة من المتزمين الفوريين لتسهيل عملية التفاهم بين القوات العسكرية والشركات الدولية من جهة والمواطن العراقي من جهة أخرى. علاوة على ذلك ، كان هناك طلب متلب متزايد و تدريجي للمتزبمين الفوريين

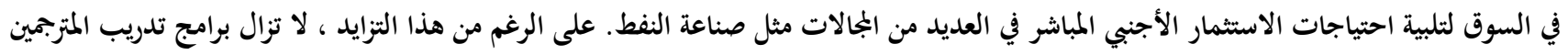

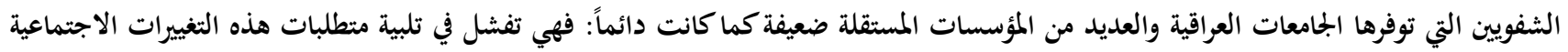

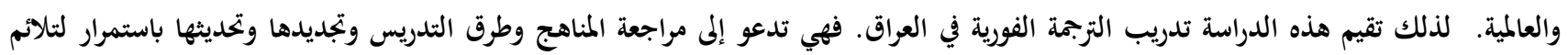
التحديات الحرجة التي يفرضها السوق الرقمي الحديث. وتقتح أيضًا عددًا من الحلول العملية الممكنة لتحسين تدريب المترجمين الفوريين ، مثل الاستعانة

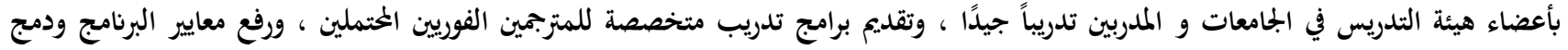
التكنولوجيا في التدريس. 


\section{Introduction}

Nowadays, there is a growing demand for competent interpreters in the Iraqi market. They are required by national and international corporations participating in reconstructing or developing infrastructural projects and income resources. For many reasons, such as security concerns and cost management, these corporations largely depend on $\mathbf{1}$ local interpreters. To win an interpreter's position offered by these corporations, candidates have to present a graduate/ postgraduate degree or certificate in translation or interpreting(or in English). Such qualification is exclusively awarded by universities or some independent institutions. Shortly after starting their first tasks, most interpreters may discover they lack skills enabling them to successfully accomplish their assignments. This dilemma could not be personal; it could be collective. This may signal a very important fact, that is, interpreters have not obtained sufficient training in the required fields. In other words, through the academic and non-academic training they receive, interpreters in Iraq are supposed to acquire the knowledge and skills entitling them to carry on their work competently. Most of them, however, are shocked when they discover that all the lectured they have attended, the drills they prepared and the tests they passed have a minor impact on their actual performance on the ground. That is why the present article tries to evaluate (simultaneous) interpreter training. It reviews the types of interpreter training courses and institutions as well as the interpreting market needs. Primarily, it does not only try to identify the obstacles that hinder providing satisfactory interpreting services to national and international clients but also suggest remedies to overcome these obstacles. It hypothesizes that simultaneous interpreter training programmes offered by Iraqi universities and several independent institutions can partially train the-would-be- interpreters to meet the needs of national and international clients. In other words, these programmes somewhat fail to prepare competent interpreters. Several factors such as poor curriculum, non-professional trainers, lack of appropriate equipment contribute to such failure.

\section{The Status Quo of Interpreter Training in Iraq}

There are two kinds of interpreter training in Iraq: academic and non-academic. Academic training is offered by the Departments of Translation in universities. Non-academic training, on the other hand, is offered by some independent language institutions.

\section{Academic Training}

Departments of Translation in Iraqi universities have been the major provider of interpreting services to the market. There are seven departments distributed across the country. The number of their (morning and evening studies) graduates has gradually increased to cater to the clients' needs. The quality of interpreting output these graduates provide is, nevertheless, unsatisfactory. The main reason behind such relative failure could be the inappropriate training they have received in university. Let's briefly examine the nature of this training.

First of all, Iraqi Departments of Translation do not train, but teach, interpreters. There is, of course, a recognizable difference between these two activities. These differences are creatively summarized by MacRae and Furnham (2018:143-148) as can be seen in the following table:

Table (1) The Differences between Teaching and Training

\begin{tabular}{|c|c|c|c|}
\hline $\begin{array}{c}\text { Cod } \\
\text { e }\end{array}$ & Aspect & Teaching & Training \\
\hline
\end{tabular}


مجلة لارك للفلسفة واللسانيات والعلوم الاجتماعية العدد (34) الاصدار 1- 7 - 2019 (ابحاث اللغة الانكليزية)

\begin{tabular}{|c|c|c|c|}
\hline 1 & $\begin{array}{c}\text { Philosop } \\
\text { hy }\end{array}$ & Theoretical/abstract & Practical/concrete \\
\hline 2 & Aim & Understanding & Doing \\
\hline 3 & Context & Independ & Specific \\
\hline 4 & $\begin{array}{c}\text { Time } \\
\text { Frame }\end{array}$ & Long term, unlimited & $\begin{array}{c}\text { Short term, } \\
\text { immediate }\end{array}$ \\
\hline 5 & $\begin{array}{c}\text { Resourc } \\
\text { es }\end{array}$ & Self-initiated & Provided \\
\hline 6 & Tone & Critical/skeptical & $\begin{array}{c}\text { Enthusiastic/zealo } \\
\text { us }\end{array}$ \\
\hline 7 & Medium & Verbal/process & $\begin{array}{c}\text { Diagrammatic/mo } \\
\text { dels }\end{array}$ \\
\hline
\end{tabular}

As a teaching staff member of one of the Departments of Translation in Iraq for more than fifteen years, the researcher totally agrees with and can reflect shortly on some of the aspects underlined above. The relevance of theory to interpreting training is undeniable, practice, however, must be prioritized. In other words, it is true that interpreters should be equipped with knowledge on interpreting methods; strategies, problems, or models, but skillfulness acquired throughout real-life practice or field work is more constructive. In fact, trainee students can hardly have the opportunity to sufficiently practice because of, for example, the high number of students in the one class (about 50 in each section) or the short time ( 3 hours per week for each section) allocated to the course. More importantly is the unavailability of suitable equipment and setting. As it is technically well-known, simultaneous interpreters work in sound-proof booths that are equipped with devices allowing them to listen and speak roughly at the same time. None of the Departments has such facilities. If are lucky enough, students can only use language labs which neither have booths nor the appropriate software programs.

Another obstacle that hinders satisfactory interpreting is the curriculum, as there are just three interpreting courses taught at three different years. These are sight interpreting $\left(2^{\text {nd }}\right.$ year $)$, consecutive interpreting $\left(3^{\text {rd }}\right.$ year), and simultaneous interpreting ( $4^{\text {th }}$ year). The items and activities that should be covered in these courses are unclear. As can be seen in Appendix (1), the only aspect decided by the Ministerial Curriculum
Development Committee as far as simultaneous interpreting is concerned is to teach 'selected texts or videos', so that whatever experience or qualification the instructor has, s/he is given high freedom to design and apply the course. As will be reflected on shortly, course instructors rarely hold an MA or Ph.D. in Translation Studies and have little or no interpreting experience. Moreover, the Ministry of Higher Education does not have a well-organized plan to train these instructors. Such factor and many other presented below may have a negative impact on the skilfulness of trainee students who will be field interpreters.

\section{Non-Academic Training}

This kind of training is produced by institutions outside academia. The contribution these institutions offer to interpreter training seems marginal. The reasons behind such ineffectiveness are miscellaneous, among them are the limitedness of authorized institutions, the shortness of sessions and the unavailability of professional trainers, suitable training equipment or well-planned curriculum. Iraqi Translators' Association (established in 1977) and Iraq's Centre in Dar Al-Maamoun for Translation and Publishing (established in 2011) are among the very few non-academic training institutions. If you visit their websites, you can see how poor the kind of interpreter training service they provide (see Appendixes (2) and (3)). Iraqi Translators' Association(www.irtrans.org), for example, declares that one of its missions is:

تنظيم دورات تخصصية في الترجمة التحريرية والشفوية لخريجي اقسام اللغات"

(i.e. to organize specialized sessions in translation and interpreting for the graduates 
from the Departments of Languages(my translation).

Iraq's Centre for Translation and Simultaneous Interpreting Training (www.dar-mamoon.mocul.iq),2 on the other hand, holds three sessions every six months. One of them only is devoted to interpreting. The participants should have a BA in English.

At first glance, it could be said that, therefore, the role of non-academic training seems not encouraging. A more objective evaluation is, however, needed. This will be profoundly tackled in the next sub-sections, but let's first shed light on contemporary interpreting market needs.

\section{Contemporary Interpreting Market Needs}

Interpreting industry has flourished after the war on Iraq in 2003. At the beginning, interpreters were required by international military (such as American, British or Australian) forces distributed across cities to facilitate communication with the citizens. With the gradual social and political stability and security, more interpreters were then required to work with national and international corporations supposed to rehabilitate the country's infrastructure and develop its income resources. Nowadays, interpreters are effectively participating in market growth by mediating between employers and their monolingual clients. The skills these interpreters should possess have become non-conventional, this is very clearly stated in job vacancies advertised. Below are a few extracts taken from these posts:

1. Name of Corporation: Mission Essential(www.missionessential.com)

Job Required: Arabic Simultaneous Interpreter/ Cultural Management Advisor

Date of Post: January 2019

\section{Job Description}

Mission Essential is seeking a Senior Simultaneous Arabic Interpreter/Cultural Management Advisor who will provide professional and expert translation support to the US Embassy Political-Military management team.

Name of Corporation: United Nations Assistance Mission for Iraq(www.uniraq.org)

Job Required: Arabic/English Interpreter Date of Post: April 2017

\section{Job Description}

The Interpreter should have the following qualifications:

\section{Professionalism:}

\section{Ability} to demonstrate a high level of concentration; split-second accuracy. Ability to work under continuous stress and deliver a clear interpretation of an exceedingly broad range of subjects. Shows pride in work and in achievements; demonstrates professional competence and mastery of subject matter; is conscientious and efficient in meeting commitments, observing deadlines and achieving results; is motivated by professional rather than personal concerns; shows persistence when faced with difficult problems or challenges; remains calm in stressful situations.

Communication: Speaks and writes clearly and effectively; listens to others, correctly interprets messages from others and responds appropriately; asks questions to clarify, and exhibits interest in having two-way communication; tailors language, tone, style and format to match audience; demonstrates openness in sharing information and keeping people informed.

As can be seen in the posts above, interpreters are required to have expertise in, for example, persistence, leadership, monitoring, 
management, cultural relations, revision and analysis of documents, presentation skills and can meet tight deadlines. That is to say, the demands of Iraqi interpreting market are constantly increasing. To meet these demands, therefore, interpreter training institutions have to carry on concrete steps such as revision and improvement of their curricula. The next subsection is assigned to objectively evaluate the available training programs.

\section{Evaluating Interpreter Training}

Systemic evaluation of training programs can be helpful in uncovering the gap between training and market needs. It may take distinct forms, carried out at particular stages, and, more importantly, differently responded to by concerned people. Before moving ahead to reflect on the various models, however, it is significant to understand what does evaluation mean. To do this, let's examine some chronologicallyorganized definitions.

Goldstein (1980:2), for example, views evaluation as 'the systematic collection of descriptive and judgment information necessary to make effective training decisions related to the selection, adoption, value, and modification of various instructional activities'. Moreover, Brown (1989:222) emphasizes that it is 'the systematic collection and analysis of all relevant information necessary to promote the improvement1. of a curriculum, and assess its effectiveness and efficiency, as well as the participants' attitudes within2. the context of the particular institutions involved'. Tyler(2010:105-106) also declares that it is 'the process of determining to what extent the educational3. objectives are actually being realized by the program of curriculum and instruction'. Similarly, Wolff et al. (2012:3) postulate that it is 'a process of gathering and analyzing information from multiple sources in order4. to improve student learning in sustainable ways.' Finally, Prasad et al (2016:144) underline that it is 'the systematic assessment of the worth or merit of some object or aim. It would simply mean the act of judging whether or not the activity to be evaluated is worthwhile in terms of set criteria'.

That is to say, there are two important activities that should be covered in the evaluation of any training program: the collection or gathering of information and the description, analysis, and judgment of this information. Because the mechanisms of collection and judgment vary, different evaluation models have been suggested (Gabr, 2001a\&b; Li, 2000; Kelly, 2005; Kearns, 2006; Pym, 2009; Pham and Tran, 2013 and Mahasneh, 2017). These have been applied to different contexts. For reasons that will be clearer soon, Gabr's (2001a) Comprehensive Quality Control Model (CQCM) will be adopted here to evaluate interpreter training in Iraq.

Gabr(2001a) assumes that Comprehensive Quality Control Model (CQCM) is solely based on feedback(through questionnaires) obtained from students (at reactional and learning levels) and instructors as well as observations( through interviews) by independent evaluators. It is applied to maintain four-interrelated functions:

Determine the successfulness of learning and transfer of knowledge.

Determine the appropriateness of the objectives, course content, and delivery to learning and skills transfer needs.

Identify the strengths (to be maintained) and the weaknesses (that need to be addressed), thus helping to improve the quality of current and future courses.

Determine the dis/continuance or revision of the course.

This model has two main phases: process initiation and curriculum development. Within the process initiation phase, four main 
steps have to be followed in sequence: forming a team of developers; brainstorming for developers; task assignment and setting deadlines for task accomplishment. Within the curriculum development phase, on the other hand, there are two stages: pre-development and development. Identifying the market and student needs should be carried out in the pre-development stage.
Nevertheless, defining instructural objectives, preparation of material, selection of teaching methods and techniques, selection of teachers and the development of lesson plans should be accomplished in the development stage. The diagram below outlines this model(Gabr, 2001b):

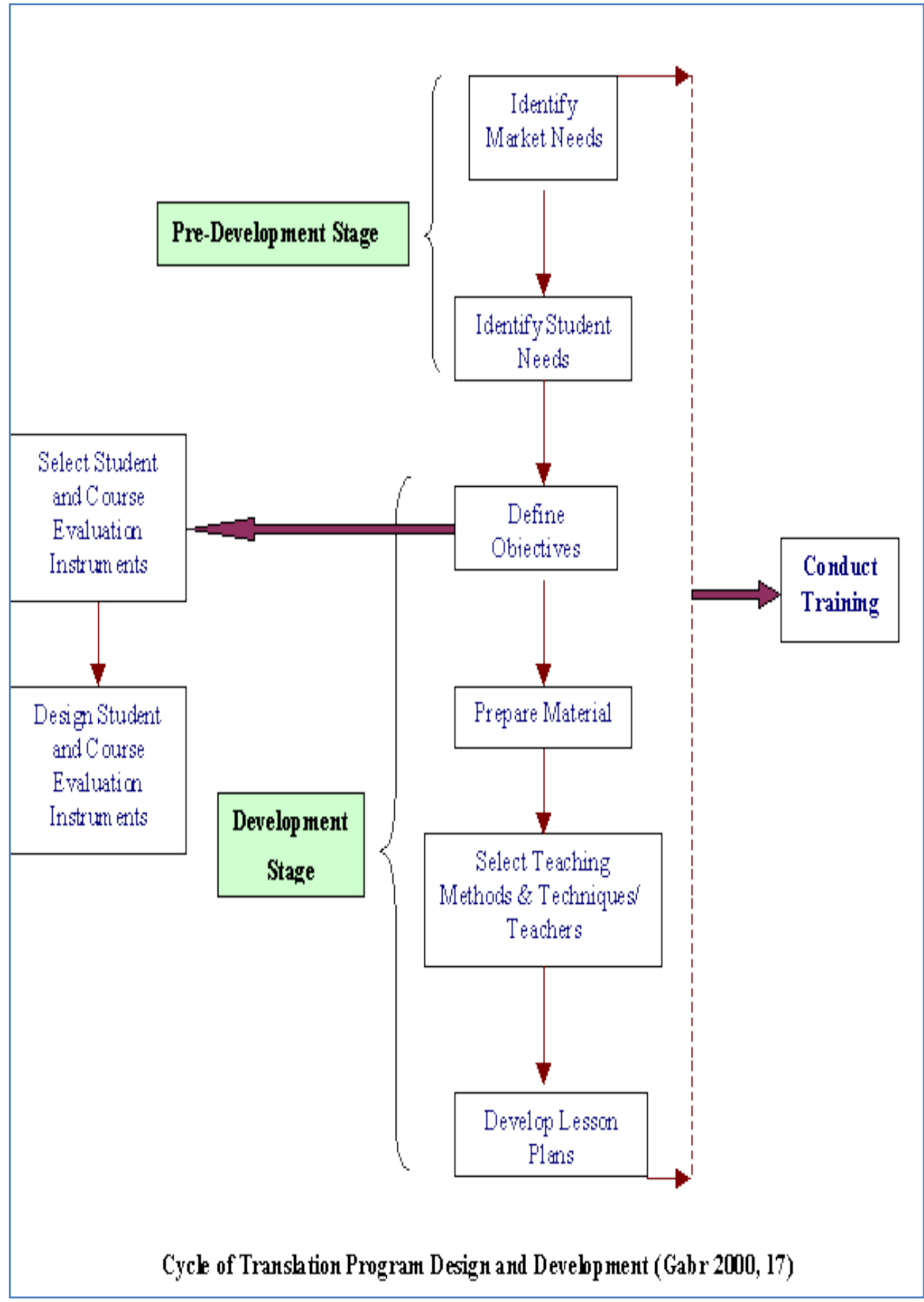

Figure (1) Cycle of Program Design and Development (adapted from Gabr, 2001b) 
In order to investigate the gap between simultaneous interpreter training and Iraqi market needs, Gabr's model of evaluation has been applied. But, because the curriculum on which the training is based has already been initiated and applied for many years, the focus was on the identification of weaknesses that may have contributed to the gap. The informants were students, instructors, and independent evaluators from the Department of Translation/the University of Basra. The questionnaires and interviews have been conducted during the academic year 2017-2018. The evaluation started with the diagnosis of market needs. These have been obtained through two ways: interviewing national and international clients and an in-depth analysis of some collected job posts. In order to cater for the market needs, therefore, the simultaneous interpreter should have most of the1. following knowledge and skills:

1. A complete mastery of target language and indepth knowledge of source language.

2. Use equipment, voice-over or whisper techniques;

3. Possess no impediments to travel overseas.

4. Interpret private and public meetings; implement and ensure quality control plan

5. Ability to analyze and construct facts.

6. Intellectual curiosity and integrity.

7. cultivate patience; observe and analyze culturespecific non-verbal indicators and cues.

8. Experience in working on different subjects such as politics, legal affairs, economic and social issues, human rights, finance, and administration.

4. Teaching methods are not helpful: they are

9. The speed of reaction and ability to adapt to speakers, situations, and subjects; excellent interpersonal and communication skills.

10. Work in a high-threat environment; good physical condition with no health deficiencies and can pass a physical fitness agility test and a preemployment drug screening.

11. Work collaboratively or autonomously.
12. Professional in self-monitoring.

13. Aware of technological advancements, especially CAT tools.

14. Flexible and can work even before a short notice.

The next step of the evaluation was spotting trainee students' needs. Therefore, a questionnaire has been conducted. The sample consisted of 30 students. They have been randomly selected (sex differences were not taken into consideration). They were asked to answer 13 questions within 40 minutes. The questions and the results obtained are outlined in Appendix (4). Statistical analysis of the feedback showed the following weaknesses:

The weekly( 3 hours) allocated for the course are insufficient. Moreover, the course itself is very short. Therefore, many students could not have the opportunity to practice in the class to improve their skills (each class consists of 40-50).

2. The course is not suitable to the students' level: it is above their level, as it mistakenly viewed them to be skillful in English. It also does not take their needs into consideration.

3. The material presented in the course is relatively irrelevant. It is selected(by instructors) in a way that diverts from the course objectives. Further, it does not reflect market needs. theoretical. Therefore, the instructor's style is unsatisfactory. Moreover, the teaching environment is not supportive: there is no interpreting equipment or booth. In addition, there are no field visits.

Instructors' feedback was then obtained. The sample consisted of 10 participants (they must have taught simultaneous interpreting at least 
for one year). They were asked to take 13 questions3. Lack of labs and suitable equipment impede within 40 minutes. The questions, as well as the answers, are summarized in Appendix (5). Analyzing students' acquisition of relevant skills, such as self-monitoring and stress management.

the feedback pointed out the following shortcomings:4. Curriculum designers tend to underestimate

1. Instructors do not often hold a Ph.D. or an MA in Translation or Interpreting Studies. They occasionally work as simultaneous interpreters. They do not the contemporary interpreting market needs. They also seem to overlook technology-based instructors training. regularly attend training sessions, especially those given by professional interpreters.

\section{Conclusion}

2. They neither evaluate nor give their students the opportunity to evaluate the course. In this respect, they are aware that the content of the course does not reflect the market needs.

The thorough study of interpreter training programs in Iraq reveals the following drawbacks:

1. The present program suffers from a number of

3. The course is old-fashioned. It is neither thoroughly revised nor improved. deficiencies, such as:

a. Instructors are immaturely given the freedom

4. There are obstacles that prevent the students from participating in the class activities, such as a large number of students in the one class, the incompetence in English, and the unavailability of proper to decide the teaching method and materials. Such freedom is risky as many instructors neither hold a degree in interpreting nor specialized in interpreting training. equipment.

b. The unavailability of proper training The last kind of feedback has been attained equipment and software.

throughout interviewing independent observers suchc. The limitedness of time allocated to the as past and present heads of department, coordinators, course.

and course instructors (other than those teachingd. The high number of trainee students in each simultaneous interpreting). They pointed out the class.

following deficiencies (full transcripts of thee. No room is devoted to the students, interviews are in Appendix (6)):

1. Students in the Department of Translation have a weak competence in English, this, of course, has af. very negative impact on their listening, instructors, independent observers, and clients to evaluate the course.

Students are not categorized according to their mastery of the foreign language(i.e. English). understanding, analysis and reproduction of messagesg. They do not get an onsite interpreting from or into this foreign language not only in simultaneous interpreting course but even on theirh. overall performance after graduation.

2. The length of the course and number of hours devoted are insufficient, as the number of students in experience because there are no field visits.

They do not undergo a supplementary training in, for example, stress management, politeness in intercultural communication, eloquence, ethics, confidentiality, and safety.

each class is large(40-50), so a student may have the2. There is a wide gap between simultaneous opportunity to participate only once or twice in each course. interpreting training and market needs. This gap is generated by the unsuccessful, need- 
based curriculum planning. For example, no links are established between curriculum designers and national and international clients.

\section{Recommendations}

1. Before they start taking the course, students have to undergo a placement test to identify their competence in English. They could be then divided into three distinct groups. Each group has to undergo a specifically designed training.

2. Instructors should either hold an MA or a Ph.D. degree in interpreting or professional simultaneous interpreters who have, at least, five-year experience. Both must attend annual training sessions.

3. Departments of Translation should have interpreting labs. These should be fully equipped with booth and simultaneous interpreting system (control panel, microphones, amplifiers, and headphones).

4. Curriculum designers are advised to establish direct and efficient channels with the clients, students, instructors, and independent observers in order to adapt the training program into their needs. That is to say, designers can follow the successive steps suggested by Gabr in order to improve interpreter training in the country.

5. Onsite interpreting practice should be a requirement that trainee students have to attend to pass the course.

\section{References}

[26] Al-Mahasneh, Anjad. (2015). Translation Curriculum Evaluation in Jordan: A New Perspective. Eastern Europe: Lambert Academic Publishing.
[27] Brown, James Dean. (1989). Language Program Evaluation: A Synthesis of Existing Possibilities. In Robert Keith Johnson, ed. The Second Language Curriculum. Cambridge: Cambridge University Press, pp. 222-41.

[28] Gabr, Moustafa. (2001a). Program Evaluation: A Missing Critical Link in Translator Training. Translation Journal, vol5, no1.

[29] Gabr, Moustafa. (2001b). Toward a Model Approach to Translation Curriculum Development. Translation Journal, vol5, no2

[30] Goldstein, Irwin. (1980). Training in Work Organizations. Annual Review of Psychology, vol 31, pp. $229-272$

[31] Kearns, John. (2006). Curriculum Renewal in Translator Training: Vocational Challenges in Academic Environments with Reference to Needs and Situation Analysis and Skills Transferability from the Contemporary Experience of Polish Translator Training Culture. Unpublished Doctoral Dissertation, Dublin City University

[32] Kelly, Dorothy. (2005). A Handbook for Translator Trainers. Manchester: St. Jerome

[33] Li, Defeng . (2000). Tailoring Translation Programs to Social Needs: A Survey of Professional Translators. Target, vol 12, pp.12749

[34] MacRae, Ian, and Adrian Furnham. (2018). Myths of Work: The Stereotypes and Assumptions Holding Your Organization Back. London, New York, and Baryaganj: Kogan Page Limited.

[35] Pham, Hiep Hoa and Ly Thi Tran (2013). Developing Graduate Knowledge and Skills for the World of Work: The Case of the Translation Curriculum in Vietnam. The Internet Journal Language, Culture and Society, Issue 36, pp. 7-17.

[36] Pym, Anthony. (2009). Exploring Translation Theories. London and New York: Routledge.

[37] Tyler, Ralph. (2010). Basic Principles of Curriculum and Instruction. Chicago University of Chicago Press.

[38] Von, Wolff, Stuart D, and Anu Viljanmaa. (2012). Research Article Twice Invisible: IntermediateLevel Student Interpreters, Interculturality, Pedagogy, and Paradigms. IJE4D Journal, vol. 1, pp. 117-131. 


\section{Appendix (1) The Curriculum of Iraqi Departments of Translation}

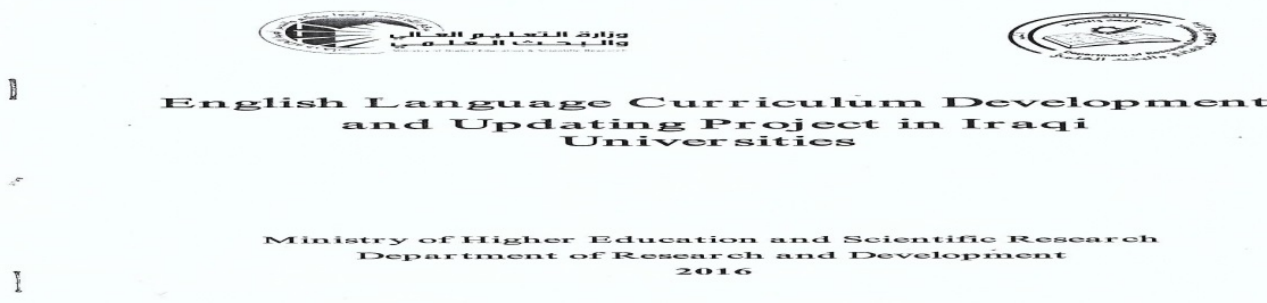

Department of Translation Syllabus

First year

\begin{tabular}{|l|l|c|c|}
\hline No- & Subject & Hours & Credits \\
\hline 1 & Principles of Translation into Arabic & 2 & 4 \\
\hline 2 & Principles of Translation into English & 2 & 4 \\
\hline 3 & English Grammar & 3 & 6 \\
\hline 4 & Composition & 2 & 4 \\
\hline 5 & Comprehension & 2 & 4 \\
\hline 6 & Pronunciation & 2 & 4 \\
\hline 7 & Literary Texts & 2 & 4 \\
\hline 8 & Arabic Grammar & 2 & 2 \\
\hline 9 & Human Rights and Democracy & 1 & 2 \\
\hline 10 & Computers & 3 & 4 \\
\hline & Total & 21 & 38 \\
\hline
\end{tabular}

Second Year

\begin{tabular}{|c|l|c|c|}
\hline No. & \multicolumn{1}{|c|}{ Subject } & Hours & Credits \\
\hline 1 & Translation into Arabic & 3 & 6 \\
\hline 2 & Translation into English & 3 & 6 \\
\hline 3 & Sight Interpreting & 3 & 6 \\
\hline 4 & English Grammar & 3 & 6 \\
\hline 5 & English Novel & 2 & 4 \\
\hline 6 & Conversation & 2 & 4 \\
\hline 7 & Arabic Grammar & 2 & 4 \\
\hline 8 & English and Arabic Lexicography & 2 & 4 \\
\hline & Total & 20 & 40 \\
\hline
\end{tabular}

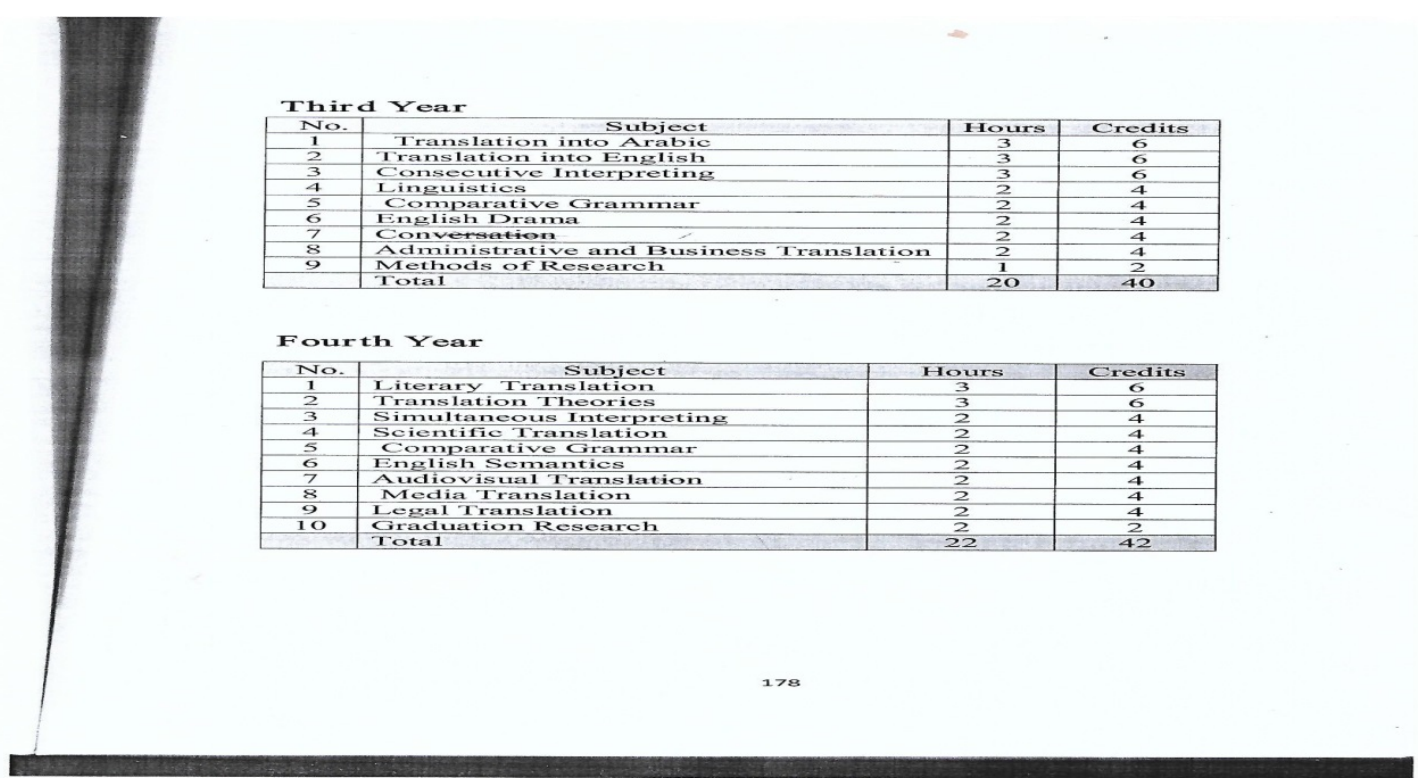




\section{Appendix (2) Website of Iraq's Centre for Translation and Interpreting}

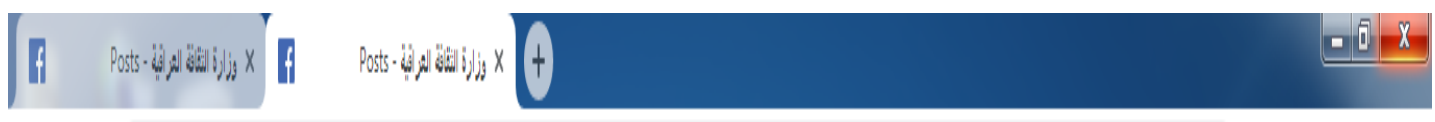

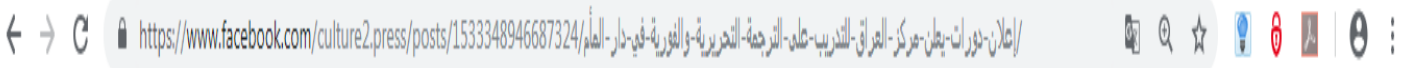

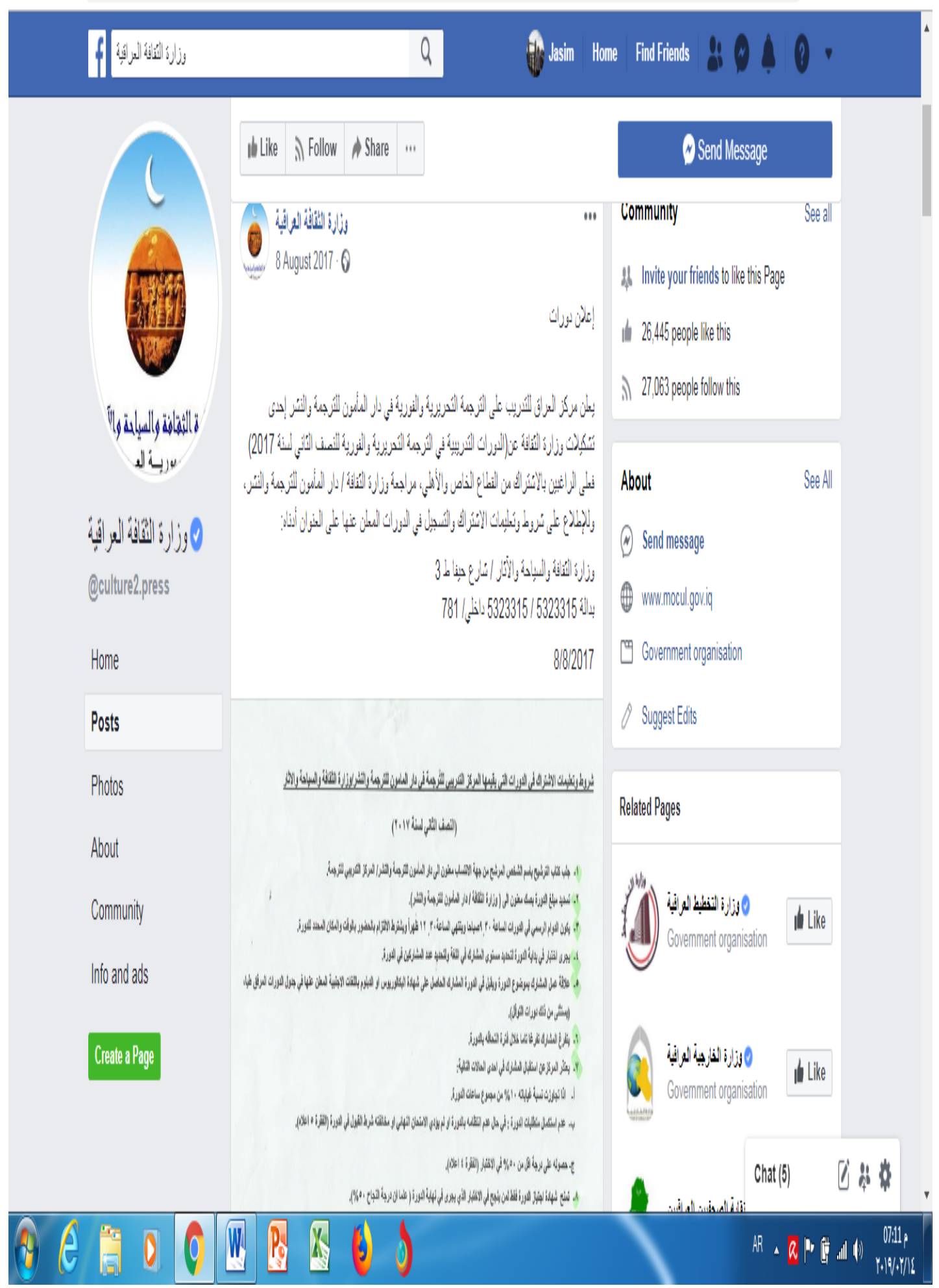

Appendix(3) Website of Iraqi Translators Association 


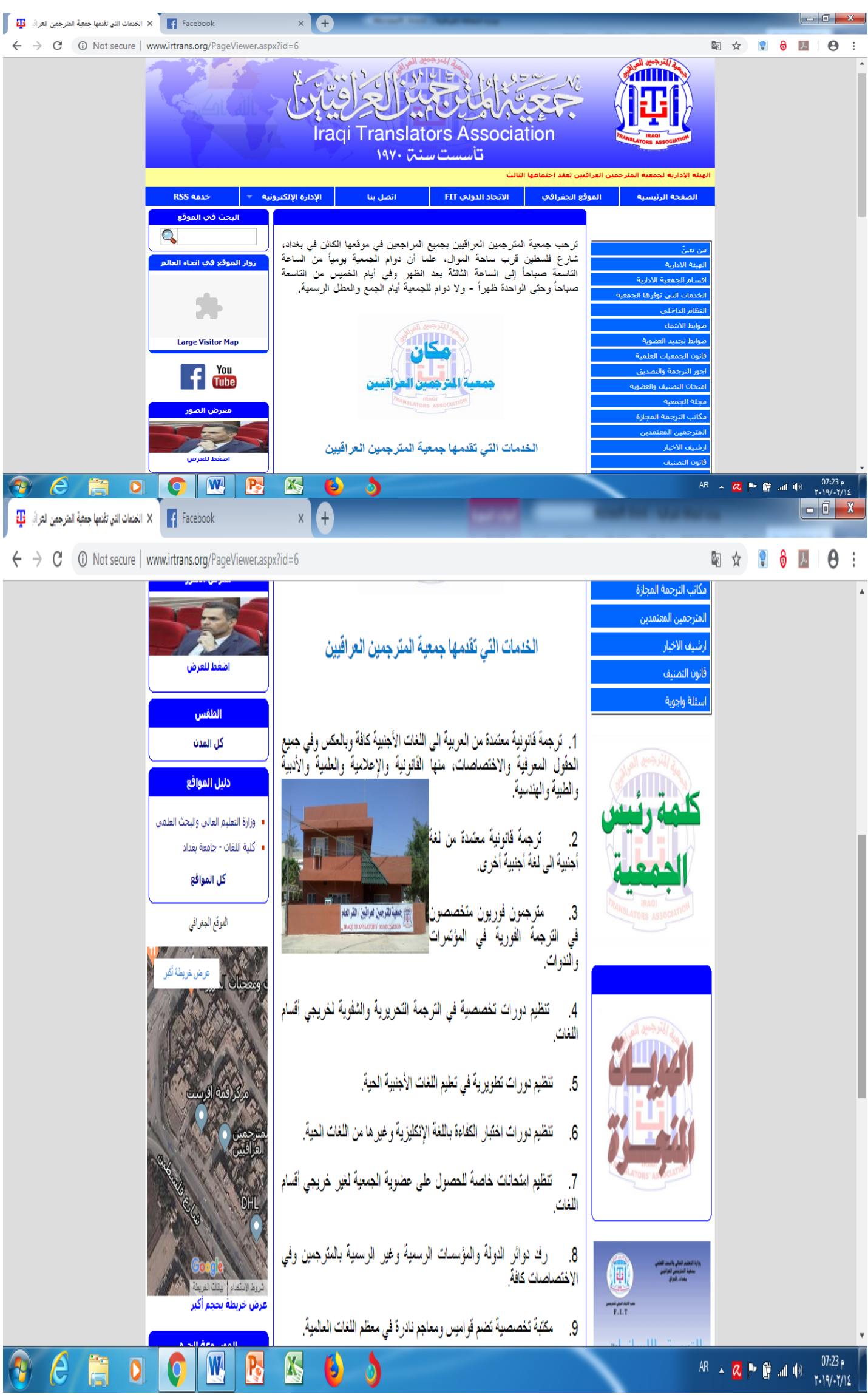

Appendix (4) Questionnaire Form Showing Students' Answers 
بجلة لارك للفلسفة واللسانيات والعلوم الاجتماعية العدد (34) الاصدار 1- 7 - 2019 (ابحاث اللغة الانكليزية)

\begin{tabular}{|c|l|c|c|c|c|c|}
\hline Code & The Question & $\begin{array}{l}\text { Strongly } \\
\text { Agree }\end{array}$ & Agree & Neutral & Disagree & $\begin{array}{l}\text { Strongly } \\
\text { Disagree }\end{array}$ \\
\hline 1 & The weekly hours allocated for the course are sufficient. & 0 & 10 & 0 & 20 & 0 \\
\hline 2 & The length of the course is satisfactory. & 0 & 7 & 0 & 23 & 0 \\
\hline 3 & The course is suitable to students' level. & 0 & 12 & 0 & 18 & 0 \\
\hline 4 & The course objectives take into consideration students' needs. & 0 & 9 & 0 & 21 & 0 \\
\hline 5 & The material presented in the course is relevant. & 0 & 13 & 0 & 17 & 0 \\
\hline 6 & $\begin{array}{l}\text { The material is selected in a way that meets the objectives of the } \\
\text { course. }\end{array}$ & 0 & 14 & 0 & 16 & 0 \\
\hline 7 & The teaching method is efficient and helpful. & 0 & 8 & 0 & 22 & 0 \\
\hline 8 & The teaching style is satisfactory. & 0 & 9 & 0 & 21 & 0 \\
\hline 9 & The learning environment is very supportive. & 0 & 3 & 0 & 27 & 0 \\
\hline 10 & Students are given the opportunity to evaluate the course. & 0 & 14 & 0 & 16 & 0 \\
\hline 11 & The performance of the instructor is satisfactory. & 0 & 13 & 0 & 17 & 0 \\
\hline 12 & The objectives of the course have been met. & 0 & 4 & 0 & 26 & 0 \\
\hline 13 & The items of the course are relevant to the market needs. & & 0 & 0 \\
\hline
\end{tabular}

\section{Appendix (5) Questionnaire Form Showing the Instructors' Answers}

\begin{tabular}{|c|c|c|c|c|c|c|}
\hline Code & The Question & Never & $\begin{array}{l}\text { Not Very } \\
\text { Often }\end{array}$ & Often & Regularly & Always \\
\hline 1 & The instructor holds a degree in Translation/interpreting Studies. & 0 & 7 & 3 & 0 & 0 \\
\hline 2 & The instructor works as a simultaneous interpreter. & 6 & 2 & 2 & 0 & 0 \\
\hline 3 & The instructor attends training sessions given by professional interpreters. & 8 & 1 & 1 & 0 & 0 \\
\hline 4 & Instructors take part in evaluating the course. & 7 & 2 & 1 & 0 & 0 \\
\hline 5 & The instructor gives the students the opportunity to evaluate the course. & 8 & 1 & 1 & 0 & 0 \\
\hline 6 & The content of the course reflects the market needs. & 7 & 2 & 1 & 0 & 0 \\
\hline 7 & Course designers revise and improve materials and activities involved. & 8 & 2 & 0 & 0 & 0 \\
\hline 8 & The time allocated to the course is sufficient. & 6 & 3 & 1 & 0 & 0 \\
\hline 9 & $\begin{array}{l}\text { There are obstacles that prevent students from participating in the } \\
\text { activities. }\end{array}$ & 1 & 1 & 1 & 6 & 0 \\
\hline 10 & Suitable equipment and facilities are available to students. & 7 & 1 & 2 & 0 & 0 \\
\hline 11 & Students are provided with knowledge of relevant models and theories. & 2 & 7 & 1 & 0 & 0 \\
\hline 12 & Students have an appropriate competence in English. & 6 & 2 & 2 & 0 & 0 \\
\hline 13 & By the end of the course, students' skills and knowledge are satisfactory. & 6 & 3 & 1 & 0 & 0 \\
\hline
\end{tabular}

\section{Appendix (6) Some Extracts taken from}

\section{Interviews with Independent Observers}

(translated into English by the researcher)

عدد الدروس المخصصة لتطوير مهارات الطلبة في الترجمة الشفوية قليلة جدا لذا يمكن ان يحدث فرق في مستوى المهارات المكتسبة عند زيادة عدد هذه المواد

و وساعاتها.
The number of courses devoted to the development of students' skills in interpreting is very low, so there can be a difference in the level of skills acquired when increasing the number and duration of these courses.

$$
\text { لذستوى اللغة الانجليزية لدى الطلبة المقبولين في قسم الترجمة غير مشجع اعتماد الية افضل يتم من خلالها اختيار الطلبة. }
$$


The level of English for students admitted to the Department of Translation is not encouraging, so a better mechanism should be adopted in the selection of students.

ينبغي على لجنة تطوير المناهج اجراء استفتاءات سنوية لمعرفة متطلبات سوق العمل لإدخاله ضمن المناهج.

The Curriculum Development Committee should conduct annual questionnaires to identify market requirements for inclusion in the curriculum.

يعاني قسم الترجمة من كثرة اعداد الطلبة في الصف الواحد مما يصعب تطوير مهارات الطلة المكتسبة.

The Department of Translation suffers from a large number of students per class, which makes it difficult to develop the skills of the students. does not have suitable laboratories to train students, which requires the teacher to follow the traditional methods.
الية قبول الطلبة في اقسام الترجمة لا تأخذ بنظر الاعتبار مهارات المتقدم والتي يجب تحديدها من خلال اقامة اختبار شفوي وتحريري. The students' acceptance mechanism in the Departments of Translation does not take into consideration the applicant's skills ( which must be determined by establishing an oral and written test).

الكثير من مدرسي مادة الترجمة الفورية لا يحملون شهادة في دراسات الترجمة.

Many instructors of simultaneous interpreting do not hold a degree in translation studies.

$$
\begin{aligned}
& \text { لا تتوفر لدى الكلية مختبرات مؤهلة لتدريب الطلبة مما يفرض على } \\
& \text { الاستاذ اتباع الطرق التقليدية. }
\end{aligned}
$$

The college 